\title{
ADMINISTRASI KESISWAAN DALAM PENDIDIKAN
}

\author{
Muh Fadli Fajrin ${ }^{1}$, Nasuha Nasuha², Muhammad Arsyam ${ }^{3}$
}

\begin{abstract}
${ }^{1}$ Sekolah Tinggi Agama Islam (STAI) Darud Dakwah Wal-Irsyad (DDI) Kota Makassar, Indonesia Email: muhfadlifajrin1234@gmail.com

${ }^{2}$ Sekolah Tinggi Agama Islam (STAI) Darud Dakwah Wal-Irsyad (DDI) Kota Makassar, Indonesia Email: nasuha2801@gmail.com

${ }^{3}$ Sekolah Tinggi Agama Islam (STAI) Darud Dakwah Wal-Irsyad (DDI) Kota Makassar, Indonesia Email: arsyam0505@gmail.com
\end{abstract}

\begin{abstract}
Abstak
Administrasi sangat diperlukan bagi kelangsungan proses belajar mengajar dalam dunia pendidikan. Semua itu tidak lepas dari keaktifan orang-orang yang menguasai administrasi dalam sekolah. Orang sering menganggap enteng administrasi tersebut, padahal kalau administrasi dipegang sama orang-orang yang kurang terampil maka administrasi tersebut akan berantakan. Orang yang memegang administrasi adalah orang yang sudah terlatih dalam bidangnya (orang yang sudah mendapat ilmu/ pelatihan). Administrasi tidak hanya dalam hal keuangan saja tetapi juga dalam kerapian/keteraturan kita dalam pembukuan. Administrasi tidak hanya dilakukan dalam waktu tertentu saja tetapi setiap hari secara sistematis. Keberhasilan pendidikan di sekolah harus ditunjang oleh pelayanan administrasi sekolah yang teratur, terarah dan terencana. Di mana dalam pelaksanaannya harus mengikuti arah jaman yang semakin bersaing dan semakin modern. Untuk itu, perlu adanya pembagian tugas ketatausahaan yang jelas dan terprogram di setiap sekolah.
\end{abstract}

Kata Kunci : Administrasi, Kesiswaan, Dalam Pendidikan

\section{A. PENDAhuluan}

Dalam dunia pendidikan pun tidak dapat dilepaskan dengan administrasi. Keberhasilan penyelenggaraan pendidikan di sekolah sangatlah tergantung dari komponen-komponen pendukung dari proses pendidikan di sekolah tersebut, seperti siswa atau peserta didik, pendidik atau guru, kurikulum, serta sarana prasarana. Semua komponen tersebut haruslah saling mendukung guna mencapai keberhasilan dalam menyelenggarakan pendidikan di sekolah.

Data dan informasi yang menggambarkan pertumbuhan dan perkembangan siswa baik perorangan maupun kelompok perlu dihimpun, dicatat dan diperlihara secara cermat dan teratur, sejak pertama kali siswa terdaftar di sekolah sampai siswa tersebut tamat sekolah.

Rangkaian kegiatan menghimpun, mencatat dan memelihara data informasi mengenai siswa termasuk dalam bidang pelayanan ketata-usahaan sekolah. Rangkaian kegiatan ini tidak selamanya dikerjakan kepala sekolah tetapi ia melimpahkan sebagian 
pekerjaan ketata-usahaan kepada guru dan pegawai tata usaha. Ikut sertanya guru dalam hal mengerjakan urusan administrasi sekolah secara keseluruhan adalah wajar, karena administrasi kelas merupakan bagian yang tak terpisahkan daripada administrasi sekolah. Dengan demikian guru khususnya guru kelas dan wali kelas tidak dapat "melepaskan diri" dari urusan administrasi kelas dan sekolah, karena seorang guru sekolah dasar/menengah dan atas, pada hakekatnya adalah seorang "administrator pendidikan".

\section{B. PEMBAHASAN}

\section{Pengertian Administrasi Kesiswaan}

Sebelum membahas lebih mendalam mengenai administrasi kesiswaan, akan lebih baik ketika mengetahui apa yang dimaksud dengan administrasi dan juga siswa atau peserta didik. Secara etimologis, perkataan adminitrasi berasal dari bahasa latin ad dan minitrare yang berarti melayani (to service), sedangkan dari bahasa Inggris adalah administrastion atau to admininter yang berarti untuk mengatur, dan mengarahkan. Sehingga Administrasi dapat dimaknai sebagai kegiatan untuk melayani, membantu, mengatur, dan mengarahkan untuk mencapai tujuan tertentu.

Menurut Drs. Ngalim Purwanto, administrasi adalah suatu proses dari semua kegiatan bersama dengan memanfaatkan semua fasilitas yang tersedia baik secara material, personal, maupun spiritual dalam usaha mencapai suatu tujuan bersama secara efektif dan efisien.

Menurut Undang-Undang No. 20 Tahun 2003, tentang Sistem Pendidikan pada Bab I, Pasal 1, ayat 4. Peserta didik adalah anggota masyarakat yang berusaha mengembangkan potensi diri melalui proses pembelajaran yang tersedia pada jalur, jenjang, dan jenis pendidikan tertentu.

Berdasarkan pengertian di atas, peserta didik/siswa adalah orang atau individu yang mendapatkan pelayanan pendidikan sesuai dengan bakat, minat, dan kemampuannya agar tumbuh dalam menerima pelajaran yang diberikan pendidik. Setelah mengetahui pengertian administrasi secara benar dan luas serta mengetahui 
pengertian siswa dalam sistem pendidikan, maka dapat diketahui bahwa administrasi kesiswaan adalah merupakan suatu penataan atau pengaturan segala aktivitas yang berkaitan dengan siswa, yaitu mulai dari masuknya siswa sampai dengan keluarnya siswa tersebut dari suatu sekolah atau lembaga (Hendyat S dan Wasty S,1982:98).

Administrasi siswa adalah seluruh proses kegiatan yang direncanakan dan diusahakan secara sengaja serta pembinaan secara continue terhadap seluruh peserta didik (dalam lembaga pendidikan yang bersangkutan) agar dapat mengikuti proses belajar mengajar (PBM) secara efektif dan efisien, demi tercapainya tujuan pendidikan yang telah ditetapkan (Gunawan, 1996:80).

A. Gaffer MS membagi administrasi kesiswaan pada tiga bidang, antara lain:

1) Pupil Inventory adalah gambaran data siswa yang ada dalam lembaga sekolah untuk mengetahui keadaan-keadaan siswa yang akan masuk sekolah dan juga untuk mengetahui pertumbuhan jumlah penduduk terutama pada usia anak sekolah. Data ini untuk menyusun perencanaan sarana prasarana, tenaga guru, termasuk juga perencanaan keuangan untuk anggaran biaya sekolah tersebut. Dan data pupil Inventory dapat digunakan menyusun rencana jangka pendek dan jangka panjang. (semua data harus ada pada administrator pendidikan/sekolah).

2) Pupil Accounting adalah data mengenai keterangan perilaku siswa di sekolah, terutama masalah absensi. Seperti, mengapa siswa terlambat masuk sekolah, atau mengapa siswa tidak masuk sekolah, masalah ini guru harus mengetahui penyebabpenyebabnya sehingga dapat membantu menyelesaikan masalah-masalah tersebut.

3) Pupil Personel Service adalah pelayanan dan usaha-usaha sekolah untuk mengembangkan prestasi siswa, pelayanan tersebut berupa bimbingan konseling yaitu dengan memberikan penyuluhan-penyuluhan kepada siswa, sehingga para siswa sadar tentang potensi bakat mintanya, kemampuannya dan mampu memecahkan masalah-masalahnya sendiri (tanpa paksaan), termasuk juga dengan kesadaranya sendiri dapat mengaplikasikan pelajaran yang telah diajarkan dalam kehidupanya sehari-hari. 


\section{Tujuan dan Manfaat dari Administrasi Kesiswaan}

Berdasarkan dari tujuan dan manfaat dari administrasi kesiswaan adalah dapat dibagi dalam beberapa hal antara lain:

1) Melakukan pencatatan murid semenjak dari proses penerimaan sampai saat murid meninggalkan sekolah karena sudah tamat mengikuti pendidikan pada sekolah itu, serta menunjang proses pembelajaran sehingga lancar, teratur, dan memberikan kontribusi pada tujuan pendidikan.

2) Dapat mengetahui kuantitas dan kualitas siswa yang ada.

3) Dapat memetakan asal siswa baik itu daerah asal ataupun sekolah asal siswa, serta setelah lulus kita juga dapat memetakan penyebaran lulusan siswa tersebut.

4) Dapat membuat suatu lingkungan pembelajaran yang nyaman, karena adanya tata tertib yang tetrulis untuk siswa.

\section{Ruang Lingkup Administrasi Kesiswaan}

Administrasi kesiswaan merupakan kegiatan-kegiatan pencatatan siswa atau peserta didik mulai dari siswa mulai masuk sekolah hingga siswa meninggalkan sekolah karena lulus atau alasan lainnya. Kepala sekolah atau lembaga pendidikan sebagai leader hendaknya mampu untuk mempersiapkan atau merencanakan hal-hal yang berkaitan dengan administrasi kesiswaan. Kegiatan-kegiatan yang dimaksud adalah

\section{a. Penerimaan Peserta Didik}

Dalam penerimaan siswa baru ini perlu direncanakan dengan baik, agar penerimaan siswa baru dapat berjalan sesuai dengan apa yang diharapkan. Dalam hal ini, juga harus memperhatikan hari-hari libur sekolah atau hari Ahad, agar tidak terjadi tabrakan dengan regristrasi siswa yang lama.

Kegiatan penerimaan siswa baru biasanya dikelola oleh panitia penerimaan siswa baru (PSB) atau panitia penerimaan murid baru (PMB). Dalam kegiatan ini Kepala Sekolah membentuk panitia atau menunjuk beberapa orang Guru untuk bertanggung jawab pada tugas tersebut. Setelah para siswa diterima lalu dilakukan pengelompokan dan orientasi sehingga secara fisik, mental dan emosional siap untuk mengikuti pendidikan di sekolah. 
Pada tahap penerimaan, tentu saja setiap orang atau individu memiliki kesempatan yang sama untuk mengikuti sebuah pembelajaran di sekolah atau lembaga pendidikan. Oleh karena hal tersebut, lembaga pendidikan harus mempersiapkan segala hal untuk menjaring calon-calon peserta didiknya. Ketika berbicara mengenai penerimaan Peserta didik, haruslah memperhatikan hal-hal sebagai berikut.

\section{b. Kebijakan Penerimaan Peserta Didik}

Kebijakan penerimaan peserta didik baru, memuat aturan mengenai jumlah peserta didik yang dapat diterima di lembaga pendidikan tersebut sesuai dengan kondisional lembaga pendidikan tersebut, seperti daya tampung, kriteria yang dapat diterima, sarana prasarana, tenaga kependidikan yang ada, jumlah peserta didik yang tinggal kelas, dsb. Selain itu kebijakan penerimaan peserta didik baru juga memuat mengenai sistem penerimaan, waktu penerimaan, serta personalia-personalia yang akan terlibat dalam proses penerimaan.

\section{c. Sistem Penerimaan Peserta Didik}

Berbicara mengenai sistem penerimaan, ada dua macam sistem penerimaan peserta didik baru, yaitu sistem promosi dan sistem seleksi. Sistem promosi merupakan sistem penerimaan yang tidak menerapkan seleksi dalam penerimaan peserta didik baru. Sehingga setiap siswa yang telah mendaftar, akan secara langsung diterima oleh lembaga pendidikan tersebut sebagai peserta didik baru.

Sistem seleksi adalah sistem penerimaan peserta didik baru yang menerapkan seleksi atau penyaringan terhadap peserta didik yang telah mendaftar. Ada tiga macam sistem seleksi, yaitu melalui seleksi DANEM, seleksi Penelusuran Minat dan Bakat (PMDK), dan seleksi berdasar hasil ujian masuk.

Seleksi melalui DANEM, berarti ketika calon peserta didik masuk dalam ranking yang ditentukan oleh sekolah, maka peserta didik tersebut dinyatakan lolos seleksi. Pada sistem ini, sekolah telah terlebih dahulu menentukan daya tampung dari peserta didik yang akan diterima. 
Seleksi PMDK, berarti seleksi melalui penelusuran prestasi yang telah diperoleh oleh calon peserta didik bisa melihat dari nilai rapor atau melalui piagam penghargaan yang telah dia peroleh. Seleksi ini memberi kesempatan pada peserta didik yang unggul di sekolah sebelumnya untuk dapat meneruskan ke jenjang berikutnya sesuai dengan bakat dan minat yang ada pada dirinya.

Sistem seleksi tes masuk, berarti calon peserta didik yang akan mendaftar untuk masuk ke sekolah atau lembaga pendidikan tersebut, harus melalui seleksi dengan ujian atau tes masuk. Ketika calon peserta didik mampu menyelesaikan tes dan sesuai dengan kriteria yang telah ditentukan maka calon peserta didik tersebut akan diterima. Sebaliknya, ketika calon peserta didik tersebut tidak dapat menyelesaikan, maka ia dinyatakan gagal.

\section{d. Kriteria Penerimaan Peserta Didik}

Kriteria adalah patokan-patokan yang menentukan bisa atau tidaknya seseorang untuk diterima sebagai peserta didik. Kriteria penerimaan peserta didik ada tiga macam, kriteria acuan patokan (standard criterian referenced), kriteria acuan norma (Norm criterian referenced), dan kriteria berdasar daya tampung sekolah. Kriteria acuan patokan merupakan penerimaan berdasarkan syarat atau kriteria yang telah ditentukan sebelumnya. Sedangkan kriteria acuan norma adalah penerimaan berdasarkan keseluruhan prestasi yang diperoleh, dijumlah, dan direrata. Kriteria berdasar daya tampung sekolah adalah penerimaan berdasar daya tampung yang telah ditentukan sehingga memenuhi kriteria ketika didalam cakupan daya tampung yang telah ditentukan.

Konsekuensi dari adanya kriteria ini adalah ketika ada calon peserta didik yang tidak memenuhi kriteria yang telah ditentukan, maka calon peserta didik akan dinyatakan gagal atau tidak diterima. Berikut penjelasan secara singkat prosedurprosedur di atas.

a) Pembentukan kepanitiaan penerimaan peserta didik baru, sebagai bentuk pengorganisasian dan pembagian tugas, perlu adanya pembentukan kepanitiaan sehingga pelaksanaan penerimaan peserta didik baru mampu berjalan secara efektif dan efisien sesuai dengan tujuan yang telah ditentukan. Mengenai format dari kepanitiaan, seperti kepanitiaan lain ada unsur ketua, sekretasis, bendahara, 
serta seksi-seksi seperti seksi pendaftaran, seksi publikasi, seksi kesekretariatan, seksi pengawasan, dll, dengan tanggung jawab tugas masing-masing.

b) Rapat penentuan peserta didik baru adalah rapat kepanitiaan tersebut mengenai ketentuan-ketentuan penerimaan peserta didik baru yang hasilnya akan dipublikasikan sebagai langkah promosi atau pengenalan terhadap sekolah atau lembaga pendidikan tersebut. Hasil rapat tersebut dituliskan atau didokumentasikan dalam sebuah buku notulen rapat, agar tercatat apa yang telah dibahas dalam rapat tersebut, sehingga dapat dilihat secara jelas mengenai hasil keputusan rapat tersebut.

c) Pembuatan, pemasangan, atau pengiriman pengumuman adalah membuat suatu promosi atau pemberitahuan mengenai penerimaan peserta didik baru kepada masyarakat. Isi dari promosi atau peberitahuan tersebut bisa berupa

1. Profil atau gambaran sekolah yang berisi penjelasan mengenai visi, misi, fasilitas sarana prasarana, prestasi, dll. Dengan diberikan mengenai gambaran sekolah, calon peserta didik mampu mengetahui kualitas dari sekolah tersebut.

2. Syarat-syarat yang harus dipenuhi di dalam pengumuman, berisi syarat atau ketentuan yang harus dipersiapkan oleh calon pendaftar bisa berupa dokumen, foto, atau ketentuan lainnya. Syarat penerimaan siswa baru ini diatur oleh KanWil Departemen Pendidikan dan Kebudayaan dengan pedoman pada ketentuan dari Departemen Pendidikan dan Kebudayaan.Misalnya syarat masuk sekolah dasar: Sudah berumur 7 tahun. Apabila semua anak yang berumur 7 tahun sudah tertampung, maka prioritas penerimaan adalah anak yang berusia 8, 9, 10, 11, 12 , dan 6.

d) Cara Mendaftar dapat dijelaskan mengenai prosedur pendaftaran dengan cara online atau langsung ke sekolah harus dijelaskan secara jelas. Sehingga memudahkan calon peserta didik dalam menyiapkan berbagai hal yang berkaitan dengan pendaftaran.

e) Waktu dan tempat pendaftaran, seleksi, dan pengumuman adalah memuat mengenai waktu dan tempat terkait dengan pendaftaran, proses seleksi, pengumuman beserta registrasi.

f) Uang pendaftaran adalah memuat keterangan tentang biaya pendaftarab dan kepada siapa harus membayar (bank atau langsung ke sekolah). 


\section{Pencatatan Peserta Didik}

Setelah melalui proses seleksi penerimaan, peserta didik yang dinyatakan lolos haruslah dicatat sebagai siswa baru di sekolah atau lembaga pendidikan tersebut. Catatan-catatan yang dimaksud adalah

a) Buku Induk atau buku Pokok yang digunakan untuk mencatat data semua anak yang pernah atau sedang mengikuti pembelajaran di sekolah tersebut. Buku induk biasanya dicatat dalam buku besar. Data yang ada dalam buku induk ini harus lengkap meliputi nomor urut, nomor induk, data dan identitas siswa yang diambil dari formulir pendaftaran. Buku induk merupakan kumpulan data siswa sepanjang masa di sekolah itu. Dalam buku induk ini juga berisi data prestasi siswa dari tahun ke tahun. Catatan dalam buku induk ini harus jelas, bersih dan rapi.

b) Buku Klapper ini membantu buku induk yang memuat data siswa yang pentingpenting. Pengisiannya dapat diambil dari buku induk, tetapi tidak selengkap buku induk. Kegunaan utama buku klaper adalah untuk memudahkan mencari data siswa, apalagi jika belum diketahui nomer induknya.

c) Buku Presensi kelas yang setiap hari diisi guna mencatat siswa yang hadir atau tidak hadir, untuk selanjutnya dihitung persentase kehadiran tiap akhir bulan.

d) Buku catatan Bimbingan dan penyuluhan untuk mancatat siswa yang meminta bimbingan dan yang telah mengikutibimbingan dan penyuluhan. Bimbingan adalah proses bantuan yang diberikan pada siswa dengan memperhatikan kemungkinan dan kenyataan tentang adanya kesulitan yang dihadapi dalam rangka perkembangan yang optimal, sehingga mereka memahami dan mengarahkan diri serta bertindak dan bersikap sesuai dengan tuntutan dan situasi lingkungan sekolah, keluarga dan masyarakat.

e) Buku Catatan Prestasi Belajar Siswa merupakan buku yang digunakan guru untuk mencatat nilai mentah yang didapat dari ulangan harian atau ulangan umum sertanilai lainnya. Selanjutnya disiapkan pula buku legger yang memuat semua nilai untuk semua mata pelajaran dalam periode tertentu. Buku legger diisi oleh seorang wali kelas yang mendapat nilai dari guru-guru lain yang mengajar di kelas yang diampunya.

f) Buku Raport yang memuat laporan hasil belajar siswa yang bersangkutan dalam mengikuti pembelajaran di sekolah tersebut.

g) Buku Mutasi yang digunakan untuk mencatat adanya murud-murid yang pindah. 


\section{Tata Tertib Peserta Didik}

Menurut Instruksi Menteri Pendidikan dan Kebudayaan tanggal : 1 Mei 1974, No. 14/U/1974, tata tertib sekolah ialah ketentuan-ketentuan yang mengataur kehidupan sekolah sehari-hari dan mengandung sangsi terhadap pelanggarannya. Tata tertib siswa ini merupakan bagian dari tata tertib sekolah. Tata tertib siswa ini memuat mengenai aturan-aturan yang menyatakan boleh-tidak boleh, benar-tidak benar, layaktidak layak, untuk ditaati oelh peserta didik dan mengandung hukuman sebagai konsekuensi bagi siswa yang melanggar aturan-aturan yang telah ditentukan.

Tujuannya agar terdapat suatu standar tingkah laku, menjunjung tinggi citra peserta didik, serta dapat mewujudkan suatu kedisplinan peserta didik dalam mengikuti pembelajaran di sekolah.

\section{KESIMPULAN}

Dari penjelasan di atas maka selaku penulis dalam artikel ini dapat memberikan gambaran secara khusus terkait dengan administrasi kesiswaan dalam pendidikan, sebagai berikut:

1. Administrasi siswa adalah seluruh proses kegiatan yang direncanakan dan diusahakan secara sengaja serta pembinaan secara continue terhadap seluruh peserta didik (dalam lembaga pendidikan yang bersangkutan) agar dapat mengikuti proses belajar mengajar (PBM) secara efektif dan efisien, demi tercapainya tujuan pendidikan yang telah ditetapkan.

2. Tujuan dan manfaat dari administrasi kesiswaan adalah untuk melakukan pencatatan murid semenjak dari proses penerimaan sampai saat murid meninggalkan sekolah karena sudah tamat mengikuti pendidikan pada sekolah itu, serta menunjang proses pembelajaran sehingga lancar, teratur, dan memberikan kontribusi pada tujuan pendidikan. Selanjutnya tujuannya adalah mengetahui kuantitas dan kualitas siswa yang ada serta dapat memetakan asal siswa baik itu daerah asal ataupun sekolah asal siswa, serta setelah lulus kita juga dapat memetakan penyebaran lulusan siswa tersebut. Adapun manfaatnya adalah dapat membuat suatu lingkungan pembelajaran yang nyaman, karena adanya tata tertib yang tetrulis untuk siswa.

3. Ruang lingkup administarsi kesiswaan meliputi penerimaan peserta didik, pencatatan peserta didik dan tata tertib peserta didik 


\section{DAFTAR PUSTAKA}

Arsi, A., I., \& Arsyam, M. (2021, January 16). Artikel Administrasi Tata Kelola Dalam Pendidikan. https://doi.org/10.31219/osf.io/wsd9r

Janna, N. M., A., kurnia, A. d., \& Arsyam, M. (2021, January 14). Administrasi Keuangan Dalam Pendidikan. https://doi.org/10.31219/osf.io/hmvcf

Ramadani, W., Dahri, M., \& Arsyam, M. (2021, January 17). ADMINITRASI KEMITRAAN SEKOLAH DENGAN MASYAKARAT. https://doi.org/10.31219/osf.io/fpm9uDwiningrum, Siti Irene Astuti. 2011. Desentralisasi dan Partisipasi Masyarakat dalam

Undang-Undang No. 20 Tahun 2003, tentang Sistem Pendidikan pada Bab I, Pasal 1, ayat 4

Arsyam, M. (2020, August 3). PENGARUH KEMAMPUAN SUPERVISIONAL KEPALA SEKOLAH DAN PERAN KOMITE SEKOLAH TERHADAP KINERJA GURU SMA NEGERI DI KOTA MAKASSAR. https://doi.org/10.31219/osf.io/j84ew

Hardiansyah, H., \& Fahmi, A. (2018, September). Strategi Tata Kelola Administrasi Pada Perguruan Tinggi Berbasis Electronic Records. In Prosiding Seminar Nasional Lembaga Penelitian Dan Pendidikan (LPP) Mandala (pp. 246-250).

Neta, Y. (2014). Model Tata Kelola Administrasi Pemerintahan Yang Baik di Daerah Otonom Baru. FIAT JUSTISIA: Jurnal Ilmu Hukum, 6(2).

Mulyasa, Endang. 2007. Manajemen Berbasis Sekolah. Bandung: PT Remaja Rosdakarya.

Makmur, Z., Arsyam, M., \& Alwi, A. M. S. (2020). Strategi Komunikasi Pembelajaran Di Rumah Dalam Lingkungan Keluarga Masa Pandemi. KOMUNIDA: Media Komunikasi dan Dakwah, 10(02), 231-241.

Arsyam, M. (2020). Manajemen pendidikan islam.

Sapada, A. O., \& Arsyam, M. (2020). Ilmu Pengetahuan dan Teknologi Menurut Pandangan Islam.

Zakirah, Z., Jumliadi, J., Arsyam, M., Herianto, H., Rusli, M., \& Alwi, A. M. Implementation of The Islamic Local Regulations in Bulukumba Regency.

Jumliadi, J., Zakirah, Z., Arsyam, M., Alwi, A. M. S., \& Fadhil, M. PEMBELAJARAN DIRUMAH DALAM LINGKUNGAN KELUARGA DI TENGAH PANDEMI COVID 19.

Kristiawan, M., \& Asvio, N. (2018). Pengelolaan Administrasi Madrasah Tsanawiyah Negeri Dalam Meningkatkan Kualitas Pendidikan Madrasah. Kelola: Jurnal Manajemen Pendidikan, 5(1), 86-95.

Arsyam, M. (2021). BAHAN AJAR ADMINISTRASI PENDIDIKAN.

Suryosubroto. 2004. Manajemen Pendidikan Di Sekolah. Jakarta: PT Rineka Cipta.

Zakirah, Z., Arsyam, M., HERIANTO, H., \& Umar, K. (2020, December 20). PENDIDIKAN DASAR (KUTTAB) MASA DAULAH ABBASIYAH (132-232 H / 750-847 M). https://doi.org/10.31219/osf.io/7t8bs 